\title{
Profil Hematologi Tikus Putih yang Diberi Latihan Intensif dan Ekstrak Kulit Pisang Kepok
}

\section{(HEMATOLOGY PROFILE RATTUS NORVEGICUS THAT GIVEN INTENSIVE TRAINING AND EXTRACT OF MUSA PARADISIACA FORMATYPICA)}

\author{
Putu Jodi Wiraguna Tangkas ${ }^{1 *}$, I Nyoman Suarsana ${ }^{2}$, I Wayan Nico Fajar Gunawan ${ }^{3}$ \\ ${ }^{1}$ Mahasiswa Program Profesi Kedokteran Hewan, Fakultas Kedokteran Hewan Universitas \\ Udayana, Jl. PB. Sudirman, Denpasar, Bali; ${ }^{2}$ Laboratorium Biokimia Veteriner, Fakultas \\ Kedokteran Hewan Universitas Udayana, Jl. PB. Sudirman, Denpasar, Bali; ${ }^{3}$ Laboratorium \\ Radiologi Veteriner, Fakultas Kedokteran Hewan Universitas Udayana, Jl. PB. Sudirman, \\ Denpasar, Bali. *Email: joditangkas42@gmail.com
}

\begin{abstract}
Abstrak
Radikal bebas berasal dari proses metabolisme dan faktor eksternal yang dapat menyebabkan tidak stabilnya sel darah. Antioksidan dapat melindungi sel darah dari serangan radikal bebas, yang bersumber dari kulit pisang. Tujuan dari penelitian ini untuk mengetahui pengaruh pemberian ekstrak kulit pisang kepok terhadap profil darah tikus putih yang diberikan latihan intensif. Rancangan Penelitian menggunakan metoda rancangan acak lengkap (RAL) dengan sampel 27 ekor tikus putih jantan (200-225 gram/ekor) dibagi menjadi 3 perlakuan yang masing-masing terdiri atas 9 ekor tikus, yaitu kelompok kontrol (P0), kelompok renang (P1), dan kelompok renang dan ekstrak pisang (P2) selama 28 hari. Spesimen darah diambil melalui vena orbitalis, selanjutnya dilakukan uji hematologi lengkap untuk mengentahui profil darah. Hasil penelitian menunjukkan bahwa kadar hemoglobin dan total eritrosit $\mathrm{P} 1$ nyata lebih rendah $(\mathrm{P}<0.05)$ dari kontrol $(\mathrm{P} 0)$, sedangkan $\mathrm{P} 2$ tidak berbeda nyata dengan kontrol (P0). Total leukosit P1 dan $\mathrm{P} 2$ tidak berbeda nyata, akan tetapi nyata lebih tinggi $(\mathrm{P}<0,05)$ dari $\mathrm{P} 0$. Netrofil dan limfosit pada $\mathrm{P} 1$ dan $\mathrm{P} 2$ nyata lebih tinggi $(\mathrm{P}<0,05)$ dari $\mathrm{P} 0$, akan tetapi eosinofil dan monosit tidak berbeda dengan P0. Kadar HCT dan MCHC perlakuan P1 nyata lebih rendah $(\mathrm{P}<0,05)$ dari kontrol, sedangkan $\mathrm{P} 2$ tidak berbeda dengan kontrol $(\mathrm{P} 1)$. Kadar MCV baik P1 maupun P2 tidak berbeda dengan kontrol (P0). Dari hasil penelitian ini dapat disimpulkan, ekstrak pisang kepok dapat mempertahankan kadar hemoglobin dan eritrosit namun belum dapat mempertahankan kadar leukosit dan nilai deferensial leukosit.

Kata kunci: tikus putih; pisang kepok; radikal bebas; profil hematologi; darah
\end{abstract}

\section{Abstract}

Free radicals come from metabolic processes and external factors that can cause unstable blood cells. Antioxidants can protect blood cells from free radical attack, which comes from banana peels. The purpose of this study was to determine the effect of giving Musa paradisiaca formatypica to the blood profile of rattus norvegicus given intensive training. The study design uses a completely randomized design method (CRD) with a sample of 27 male Rattus norvegicus (200-225 grams/head) divided into 3 treatments, each consisting of 9 mice, namely the control group (P0), swimming group (P1), and swimming and banana extract (P2) groups for 28 days. Blood specimens taken through the orbital vein, then a complete hematological test performed to determine the hematology profile. The results showed that hemoglobin levels and total erythrocyte $\mathrm{P} 1$ were significantly lower $(\mathrm{P}<0.05)$ than controls (P0), whereas $\mathrm{P} 2$ was not significantly different from controls (P0). Total leukocyte cells P1 and $\mathrm{P} 2$ were not significantly different, but were significantly higher $(\mathrm{P}<0.05)$ than $\mathrm{P} 0$. Neutrophils and lymphocytes $\mathrm{P} 1$ and $\mathrm{P} 2$ were significantly higher $(\mathrm{P}<0.05)$ than $\mathrm{P} 0$, but eosinophils and monocytes did not differ from P0. HCT and MCHC levels P1 treatment were significantly lower $(\mathrm{P}<0.05)$ than controls, whereas P2 was not different from controls (P1). MCV levels of both P1 and P2 did not differ from controls (P0). From the results of this study it can be concluded, Musa paradisiaca formatypica can maintain levels of hemoglobin and erythrocytes but have not been able to maintain leukocyte levels and leukocyte differential values.

Keywords: Rattus norvegicus; musa paradisiaca formatypica; free radicals; hematology profile; blood 


\section{PENDAHULUAN}

Dewasa ini perubahan pola hidup masyarakat serta pola makan yang tidak benar dan bertambahnya usia mengakibatkan pembentukan radikal bebas dalam tubuh (Handayani et al., 2018). Radikal bebas merupakan atom atau molekul yang mengandung elektron yang tidak berpasangan yang sangat reaktif dengan molekul lain sehingga mengambil elektron dari molekul lain yang menyebabkan reaksi berantai yang dapat merusak sel. Radikal bebas dapat menyebabkan terjadinya penyakit degeneratif seperti kanker, diabetes melitus dan alzheimer. Oleh karena itu, diperlukan senyawa yang dapat meredam efek negatif dari radikal bebas yaitu antioksidan (Jami'ah et al., 2018)

Antioksidan adalah senyawa yang memiliki peranan penting dalam menjaga kesehatan karena dapat menangkap molekul radikal bebas sehingga menghambat reaksi oksidatif dalam tubuh yang merupakan penyebab berbagai penyakit (Adawiah et al., 2015). Menurut Moniharapon et al., (2016) antioksidan merupakan senyawa pemberi elektron (electron donor) atau reduktan. Senyawa ini memiliki berat molekul kecil, tetapi mampu menginaktivasi berkembangnya reaksi oksidasi, dengan cara mencegah terbentuknya radikal.

Darah merupakan komponen yang sangat penting karena berfungsi untuk mengedarkan substansi yang masuk ke dalam tubuh maupun yang dihasilkan tubuh dari proses-proses metabolisme. Oleh karena itu darah menjadi salah satu parameter pokok dalam penelitian praklinik atau biomedik. Hematologi adalah ilmu yang mempelajari cara penilaian darah. Nilai hematologi (profil darah) berguna untuk menilai kondisi kesehatan dan sebagai acuan nilai awal (baseline) atau kontrol dalam suatu penelitian. Adanya gangguan metabolisme, penyakit, kerusakan struktur dan/atau fungsi organ, pengaruh agen atau obat, dan stres dapat diketahui dari perubahan profil darah (Iheidioha et al., 2012). Radikal bebas dapat dihasilkan dari hasil metabolisme tubuh dan faktor eksternal. Menurut Ghasemian et al. (2006), radikal bebas dalam tubuh dapat disebabkan oleh metabolisme dan faktor eksternal, yaitu hasil samping proses oksidasi atau pembakaran saat proses bernafas, olahraga yang berlebihan atau latihan intensif, sedangkan yang berasal dari lingkungan adalah pada saat terkena serangan polusi lingkungan dari asap rokok, kendaran bermotor, dan radiasi. Menurut Zaetun et al. (2018), radikal bebas dapat menyebabkan stres oksidatif, karena ketidakseimbangan antara oksidan dan antioksidan yang berpotensi menyebabkan kerusakan sel. Untuk melindungi tubuh dari radikal bebas, terdapat senyawa antioksidan sebagai penangkal dan dapat menstabilkan radikal bebas dengan melengkapi kekurangan elektron radikal bebas sehingga dapat menghambat terjadinya reaksi berantai (Julfitriyani et al., 2016). Oleh karena itu, perlu dilakukan usaha usaha untuk melindungi molekulmolekul yang sangat diperlukan oleh tubuh dari serangan radikal bebas dengan memberikan antioksidan yang bersumber dari pisang (Helmi et al., 2007).

Pisang adalah salah satu komoditas buah unggulan Indonesia. Luas panen dan produksi pisang selalu menempati posisi pertama (Wibowo et al., 2010). Kulit pisang kepok merupakan salah satu limbah pertanian yang belum banyak dimanfaatkan masyarakat (Setiawan et al., 2013). Pisang kepok mengkal memiliki kandungan vitamin C yang tinggi (Pary et al., 2016), dimana vitamin $C$ mempunyai sifat antioksidan potensial yang dapat melindungi molekul-molekul yang sangat diperlukan oleh tubuh (Helmi et al., 2007). Menurut Supriyanti et al. (2015) ekstrak kulit pisang kepok memiliki aktivitas antioksidan yang lebih tinggi jika dibandingkan dengan kulit pisang lainya. Ekstrak kulit pisang kepok mengandung 
antioksidan dengan aktivitas 95,14\%. Penulisan penelitian ini untuk memberikan informasi ilmiah tentang potensi ekstrak kulit pisang kepok (Musa paradisiaca formatypica) sebagai sumber antioksidan yang dapat menangkal radikal bebas yang terbentuk pada tikus putih (Rattus norvegicus) yang diberikan latihan intensif.

\section{METODE PENELITIAN}

\section{Sampel Penelitian}

Obyek yang digunakan dalam penelitian ini adalah 27 ekor tikus putih (Rattus norvegicus) jantan dengan bobot badan $200-225 \mathrm{~g}$.

\section{Rancangan Penelitian}

Penelitian ini bersifat eksperimental dengan metode rancangan acak lengkap (RAL), yang di bagi menjadi tiga kelompok perlakuan yaitu tikus kelompok kontrol (P0), tikus perlakuan renang (P1), dan tikus perlakuan renang dengan pemberian ekstrak kulit pisang kepok (P2) masing masing kelompok terdiri atas 9 ekor tikus.

\section{Pembuatan Ekstrak Kulit Pisang Kepok}

Pembuatan ekstrak kulit pisang kepok dibuat setiap seminggu sekali. Cara pembuatan pertama pilih kulit pisang kepok mengkal dengan ciri warna kulit hijau kekuningan. Kulit pisang yang telah diambil terlebih dahulu dicuci untuk menghilangkan kotoran yang melekat pada kulit pisang tersebut hingga bersih. Potong kulit pisang kecil-kecil kemudian masukan sebanyak $100 \mathrm{~g}$, tambahkan air sampai volume menjadi $100 \mathrm{ml}$. Selanjutnya di blender selama kurang lebih 5 menit sampai kulit benar-benar hancur. Saring hasil blenderan hingga didapatkan ekstrak dari kulit pisang kepok tersebut.

\section{Perlakuan Hewan Coba}

Sebelum perlakuan hewan percobaan adapasi pada lingkungan atau laboratorium selama 7 hari, dimana pada saat adaptasi dan perlakuan diberikan minum dan pakan komersilal pellet babi 550 yang bersifat adlibitum. Perlakuan (P1) tikus diberikan perlakuan renang selama 1 jam. Pada perlakuan (P2) diberikan ekstrak kulit pisang kepok dengan menggunakan sonde lambung secara oral sebanyak 1cc, 30 menit setelah pemberian ekstrak kulit pisang kepok, tikus diberikan perlakuan renang selama 1 jam. Perlakuan renang dilakukan 1 kali setiap hari selama 28 hari.

\section{Pengambilan Data}

Pada hari ke 29 dengan dosis anjuran ketamine tikus $75-100 \mathrm{mg} / \mathrm{kg} \mathrm{BB}$, tikus dianastesi menggunakan ketamine dengan dosis $0,15-0,2$ cc per tikus dengan sediaan $100 \mathrm{mg} / \mathrm{ml}$ sebelum dilakukan pengambilan sampel darah. Darah diambil melalui vena orbitalis menggunakan pipet kapiler, kemudian di tampung dalam tabung EDTA (Ethylene Diamine Tetra Acid) sebanyak 3 cc dan dimasukan ke dalam cool box.

\section{Pemeriksaan Darah}

Nilai hematologi darah dianalisis menggunakan alat hematology analyzer Sysmex XS-800i UPT. Balai Laboratorium Kesehatan Provinsi Bali. Analisis meliputi parameter nilai $\mathrm{Hb}$, jumlah eritrosit, leukosit, nilai difrensial leukosit, HCT, MCV dan MCHC.

\section{Analisis Data}

Data yang diperoleh diuji menggunakan analisis sidik ragam (ANOVA). Apabila terdapat perbedaan yang nyata, dilanjutkan dengan uji Duncan, untuk mengetahui pengaruh pemberian ekstrak kulit pisang kepok.

\section{HASIL DAN PEMBAHASAN}

\section{Hasil}

\section{Profil Darah dan Deferensial Leukosit}

Hasil penelitian profil hematologi disajikan pada Tabel 1, Tabel 2, dan Tabel 3. Pada Tabel 1 disajikan profil darah meliputi hemoglobin $(\mathrm{Hb})$, Eritrosit (RBC), dan Leukosit (WBC), pada Tabel 2 disajikan profil darah yang meliputi Hematokrit (HCT), Mean Corpuscular Volume (MCV), dan Mean Corpuscular Hemoglobin Concentration (MCHC), dan Tabel 3 terkait nilai deferensial leukosit yang meliputi Neutrofil, Eosinofil, Limfosit, dan Monosit. 
Tabel 1. Rata-rata \pm SD profil hematologi tikus putih (Hb, RBC, dan WBC), tikus perlakuan.

\begin{tabular}{llll}
\hline Kelompok & \multicolumn{3}{c}{ Variabel } \\
\cline { 2 - 4 } Perlakuan & $\mathrm{Hb}(\mathrm{g} / \mathrm{dL})$ & $\mathrm{RBC}\left(\mathrm{x} 10^{6} / \mu \mathrm{L}\right)$ & $\mathrm{WBC}\left(\mathrm{x} \mathrm{10} 0^{3} / \mu \mathrm{L}\right)$ \\
\hline P0 & $14,9 \pm 0,97^{\mathrm{b}}$ & $7,51 \pm 0,53^{\mathrm{b}}$ & $7,56 \pm 0,44^{\mathrm{a}}$ \\
P1 & $12,9 \pm 0,88^{\mathrm{a}}$ & $6,87 \pm 0,44^{\mathrm{a}}$ & $10,8 \pm 1,65^{\mathrm{b}}$ \\
P2 & $14,7 \pm 0,53^{\mathrm{b}}$ & $7,55 \pm 0,16^{\mathrm{b}}$ & $10 \pm 0,83^{\mathrm{b}}$ \\
\hline
\end{tabular}

P0: Tikus Kontrol

P1: Tikus yang diberikan latihan intensif

P2: Tikus yang diberikan ekstrak dan latihan intensif

Huruf superkrif berbeda pada kolom yang sama menunjukkan adanya perbedaan yang nyata antara kelompok perlakuan $(\mathrm{P}<0,05)$

Tabel 2. Rata-rata \pm SD profil hematologi tikus putih (HCT, MCV, dan MCHC), tikus perlakuan.

\begin{tabular}{cccc}
\hline Kelompok & \multicolumn{3}{c}{ Variabel } \\
\cline { 2 - 4 } Perlakuan & HCT $(\%)$ & MCV (fl) & MCHC $(\mathrm{g} / \mathrm{dL})$ \\
\hline P0 & $41,4 \pm 1,85^{\mathrm{b}}$ & $55,3 \pm 3,45^{\mathrm{a}}$ & $35,8 \pm 2^{\mathrm{b}}$ \\
\hline P1 & $39,1 \pm 3,06^{\mathrm{a}}$ & $57 \pm 3,74^{\mathrm{a}}$ & $33 \pm 0,97^{\mathrm{a}}$ \\
\hline P2 & $41,7 \pm 1,61^{\mathrm{b}}$ & $55,2 \pm 21,7^{\mathrm{a}}$ & $35,3 \pm 1,64^{\mathrm{b}}$ \\
\hline
\end{tabular}

Keterangan

P0: Tikus Kontrol

P1: Tikus yang diberikan latihan intensif

P2: Tikus yang diberikan ekstrak dan latihan intensif

Huruf superkrif berbeda pada kolom yang sama menunjukkan adanya perbedaan yang nyata antara kelompok perlakuan $(\mathrm{P}<0,05)$

Tabel 3. Rata-rata \pm SD nilai deferensial leukosit tikus putih (Neutrofil, Limfosit, Eusinofil, dan Monosit), tikus perlakuan

\begin{tabular}{ccccc}
\hline \multirow{2}{*}{$\begin{array}{c}\text { Kelompok } \\
\text { Perlakuan }\end{array}$} & $\begin{array}{c}\text { Neutrofil } \\
\left(\times 10^{3} / \mu \mathrm{L}\right)\end{array}$ & $\begin{array}{c}\text { Limfosit } \\
\left(\times 10^{3} / \mu \mathrm{L}\right)\end{array}$ & $\begin{array}{c}\text { Eusinofil } \\
\left(\mathrm{x} 10^{3} / \mu \mathrm{L}\right)\end{array}$ & $\begin{array}{c}\text { Monosit } \\
\left(\mathrm{x} 10^{3} / \mu \mathrm{L}\right)\end{array}$ \\
\hline $\mathrm{P} 0$ & $1,15 \pm 0,26^{\mathrm{a}}$ & $5,9 \pm 0,4^{\mathrm{a}}$ & $0,04 \pm 0,02^{\mathrm{a}}$ & $0,5 \pm 0,17^{\mathrm{a}}$ \\
\hline $\mathrm{P} 1$ & $2,18 \pm 0,39^{\mathrm{c}}$ & $8,04 \pm 1,63^{\mathrm{b}}$ & $0,06 \pm 0,02^{\mathrm{a}}$ & $0,5 \pm 0,07^{\mathrm{a}}$ \\
\hline $\mathrm{P} 2$ & $1,7 \pm 0,47^{\mathrm{b}}$ & $7,76 \pm 0,5^{\mathrm{b}}$ & $0,06 \pm 0,04^{\mathrm{a}}$ & $0,5 \pm 0,32^{\mathrm{a}}$ \\
\hline
\end{tabular}

Keterangan

P0: Tikus Kontrol

P1: Tikus yang diberikan latihan intensif

P2: Tikus yang diberikan ekstrak dan latihan intensif

Huruf superkrif berbeda pada kolom yang sama menunjukkan adanya perbedaan yang nyata antara kelompok perlakuan $(\mathrm{P}<0,05)$

Berdasarkan hasil Tabel 1 menunjukkan penurunan jumlah hemoglobin $(\mathrm{Hb})$ pada P1 $(12,9 \pm 0,88$ $\mathrm{g} / \mathrm{dL})$ yang menunjukan hasil berbeda $(\mathrm{P}<0,05)$ terhadap P0 $(14,9 \pm 0,97 \mathrm{~g} / \mathrm{dL})$, sedangkan pada $\mathrm{P} 2(14,7 \pm 0,53 \mathrm{~g} / \mathrm{dL})$ menunjukkan hasil yang tidak berbeda
$(\mathrm{P}>0,05)$ terhadap $\mathrm{P} 0(14,9 \pm 0,97 \mathrm{~g} / \mathrm{dL})$. Hasil jumlah erittosit (RBC) mengalami penurunan pada $\mathrm{P} 1\left(6,87 \pm 0,44 \times 10^{6} / \mu \mathrm{L}\right)$ yang menunjukkan hasil yang berbeda $(\mathrm{P}<0,05) \quad$ terhadap P0 $\quad(7,51 \pm 0,53$ $\left.\mathrm{x} 10^{6} / \mu \mathrm{L}\right)$, sedangkan $\mathrm{P} 2(7,55 \pm 0,16$ $\left.\mathrm{x} 10^{6} / \mu \mathrm{L}\right)$ menunjukkan hasil yang tidak 
berbeda $(\mathrm{P}>0,05)$ terhadap $\mathrm{P} 0(7,51 \pm 0,53$ $\mathrm{x} 10^{6} / \mu \mathrm{L}$ ). Hasil jumlah leukosit (WBC) mengalami peningkatan pada kelompok perlakuan $\mathrm{P} 1\left(10,8 \pm 1,65 \times 10^{3} / \mu \mathrm{L}\right)$ dan $\mathrm{P} 2$ $\left(10 \pm 0,83 \times 10^{3} / \mu \mathrm{L}\right)$ yang menyatakan tidak berbeda $(\mathrm{P}>0,05)$, sedangankan terhadap $\mathrm{P} 0\left(7,56 \pm 0,44 \times 10^{3} / \mu \mathrm{L}\right)$ menyatakan hasil yang berbeda $(\mathrm{P}<0,05)$.

Berdasarkan hasil Tabel 2 menunjukkan hasil profil hematologi Hematokrit (HCT) pada perlakuan P1 mengalami penurunan $(39,1 \pm 3,06 \%)$ yang menunjukkan hasil yang berbeda $(\mathrm{P}<0,05)$ terhadap P0 $(41,4 \pm 1,85 \%)$, sedangkan hasil P2 (41,7 $\pm 1,61 \%)$ menunjukkan hasil tidak berbeda $(\mathrm{P}>0,05)$ terhadap P0 $(41,4 \pm$ $1,85 \%)$. Hasil dari Mean Corpuscular Volume (MCV), P1 (57 $\pm 3,74 \mathrm{fl})$ dan P2 $(55,2 \pm 21,7 \mathrm{fl})$ menunjukkan hasil yang tidak bererbeda $(\mathrm{P}>0,05)$ terhadap $\mathrm{P} 0(55,3$ \pm 3,45 fl). Hasil hematologi darah Mean Corpuscular Hemoglobin Concentration (MCHC), dimana P1 $(33 \pm 0,97 \mathrm{~g} / \mathrm{dL})$ menunjukkan hasil berbeda $(\mathrm{P}<0,05)$ terhadap P0 $(35,8 \pm 2 \mathrm{~g} / \mathrm{dL})$, sedangkan P2 $(35,3 \pm 1,64 \mathrm{~g} / \mathrm{dL})$ menunjukkan hasil tidak berbeda $(\mathrm{P}>0,05)$ terhadap $\mathrm{P} 0(35,8 \pm 2$ $\mathrm{g} / \mathrm{dL})$.

Berdasarkan tabel 3 menunjukkan hasil peningkatan deferensial leukosit neutrofil P1 $\left(2,18 \pm 0,39 \times 10^{3} / \mu \mathrm{L}\right)$ menunjukkan hasil yang berbeda $(\mathrm{P}<0,05)$ terhadap $\mathrm{P} 0$ $\left(1,15 \pm 0,26 \times 10^{3} / \mu \mathrm{L}\right)$, dan juga terjadi peningkatan pada $\mathrm{P} 2\left(1,7 \pm 0,47 \times 10^{3} / \mu \mathrm{L}\right)$ menunjukkan hasil yang berbeda $(\mathrm{P}<0,05)$ terhadap $\mathrm{P} 0 \quad\left(1,15 \pm 0,26 \times 10^{3} / \mu \mathrm{L}\right)$. Peningkatan deferensial leukosit limfosit $\mathrm{P} 1\left(8,04 \pm 1,63 \times 10^{3} / \mu \mathrm{L}\right)$ dan P2 $(7,76 \pm 0,5$ $\left.\mathrm{x} 10^{3} / \mu \mathrm{L}\right)$ menunjukkan hasil yang berbeda $(\mathrm{P}<0,05)$ terhadap $\mathrm{P} 0\left(5,9 \pm 0,4 \times 10^{3} / \mu \mathrm{L}\right)$. Hasil penelitian menunjukkan peningkkatan deferensial leukosit eusinofil $\mathrm{P} 1\left(0,06 \pm 0,02 \times 10^{3} / \mu \mathrm{L}\right)$ dan P2 $(0,06 \pm$ $\left.0,04 \times 10^{3} / \mu \mathrm{L}\right)$ menunjukkan hasil yang tidak berbeda $(\mathrm{P}>0,05)$ terhadap $\mathrm{P} 0(0,04 \pm$ $\left.0,02 \times 10^{3} / \mu \mathrm{L}\right)$. Hasil deferensial leukosit monosit $(\mathrm{P} 1)\left(0,5 \pm 0,07 \times 10^{3} / \mu \mathrm{L}\right)$ dan $\mathrm{P} 2$ $\left(0,5 \pm 0,32 \times 10^{3} / \mu \mathrm{L}\right)$ tidak menunjukkan hasil tidak berbeda $(\mathrm{P}>0,05)$ terhadap $\mathrm{P} 0$ $\left(0,5 \pm 0,17 \times 10^{3} / \mu \mathrm{L}\right)$.

\section{Pembahasan \\ Hemogobin (Hb)}

Kadar $\mathrm{Hb}$ pada tikus kelompok perlakuan (P2) memiliki kadar Hb sebesar $14,7 \pm 0,53 \mathrm{~g} / \mathrm{dL}$ dan tidak berbeda nyata dibandingkan dengan tikus kelompok kontrol (P0) 14,9 $\pm 0,97 \mathrm{~g} / \mathrm{dL}$. Hal ini diduga senyawa aktif dan vitamin yang ada pada kulit pisang dapat membantu mempertahankan nilai $\mathrm{Hb}$ pada perlakuan (P2).

Hal ini sesuai dengan penelitian Pary et al. (2016) kulit pisang kepok mengkal memiliki kadar vitamin $\mathrm{C}$ yang tinggi. Menurut Sembiring et al. (2013) pemberian vitamin $\mathrm{C}$ dapat membantu penyerapan zat besi (Fe) yang berperan dalam pembentukan dan pematangan eritrosit, vitamin $\mathrm{C}$ dapat meningkatkan produksi eritrosit yang berbanding positif terhadap hemoglobin, dengan cara memobilisasi simpanan zat besi $(\mathrm{Fe})$ di jaringan dalam bentuk hemosiderin. Sehingga dalam penelitian ini tikus kelompok perlakuan (P2) yang diberikan perlakuan renang (latihan intensif) dan pemberian ekstrak kulit pisang kepok menyebabkan kadar hemoglobin darah menjadi stabil dan tidak berbeda nyata $(\mathrm{P}>0,05)$ dengan kelompok kontrol (P0).

Nilai kadar $\mathrm{Hb}$ pada tikus kelompok perlakuan (P1) menunjukkan hasil yang berbeda nyata terhadap kontrol (P0), dimana penurunan tersebut di akibatkan oleh perlakuan renang yang memicu terjadinya radikal bebas yang menyebabkan penurunan kadar hemoglobin. Menurut Rusmini et al. (2019) yang menyatakan stres oksidatif menyebabkan hilangnya fluiditas dan meningkatkan fragilitas peroksida lipid pada membran eritrosit sehingga eritrosit akan mudah lisis. Lisisnya membran eritosit menyebabkan hemoglobin terbebas ke dalam plasma, sehingga jumlah hemoglobin semakin berkurang, hal ini mengakibatkan kadar hemoglobin yang terdapat dalam eritrosit rendah. 


\section{Sel Darah Merah (Red Blood Cell /RBC)}

Hasil penelitian menunjukkan tikus kelompok perlakuan yang diberikan ekstrak kulit pisang kepok dan latihan intensif (P2) mendapatkan hasil 7,55 $\pm 0,16$ menunjukkan hasil yang tidak berbeda nyata terhadap tikus kelompok kontrol (P0) mendapatkan hasil 7,51 $\pm 0,53$. Menurut Zulkifli et al. (2014) kandungan vitamin C mampu meningkatkan jumlah eritrosit dan kadar $\mathrm{Hb}$ dalam darah tikus putih anemia. Fungsi vitamin $\mathrm{C}$ dalam darah yaitu membantu penyerapan zat besi $(\mathrm{Fe})$, sehingga zat besi $(\mathrm{Fe})$ dan vitamin $\mathrm{C}$ saling berhubungan dalam pembentukan dan pematangan eritrosit (Sembiring et al., 2013). Sehingga dalam penelitian ini tikus kelompok perlakuan yang diberikan perlakuan renang dengan pemberian ekstrak kulit pisang kepok (P2), memiliki kadar eritrosit yang stabil dan tidak berbeda nyata $(\mathrm{P}>0,05)$ dibandingkan dengan tikus kelompok kontrol (P0).

Kadar eritrosit tikus kelompok perlakuan $(\mathrm{P} 1) \quad 6,87 \quad \pm \quad 0,44$ dan menunjukkan hasil yang berbeda nyata dibandingkan dengan tikus kelompok kontrol (P0) yang memiliki kadar eritrosit $7.51 \pm 0.53$. Penurunan kadar eritrosit pada (P1) diduga akibat oleh aktivitas renang, yang dapat memicu timbulnya radikal bebas dalam tubuh.

Penurunan eritrosit disebabkan karena radikal bebas yang akan mengikat protein, DNA dan lipid penyusun membran sel (Heryani et al., 2011). Radikal bebas juga berpengaruh terhadap hormon eritropoietin yang merupakan suatu hormon glikoprotein yang penting pada proses eritropoiesis terutama dalam merangsang proliferasi sel eritrosit, yang menyebabkan menurunnya kadar eritrosit dalam darah (Suryanty dan lubis, 2005)

\section{Sel Darah Putih (White Blood Cell/ WBC)}

Hasil penelitian tikus kelompok perlakuan (P2) memiliki nilai leukosit $10 \pm$ 0,83 dan tikus kelompok perlakuan (P1) juga memiliki nilai leukosit 10,8 $\pm 1,65$ yang menunjukkan hasil yang berbeda nyata terhadap tikus kelompok kontrol (P0) memiliki nilai leukosit 7,56 $\pm 0,44$. Tikus kelompok perlakuan (P1) memiliki nilai yang lebih tinggi dibandingkan dengan tikus kelompok perlakuan (P2).

Tikus kelompok perlakuan (P1) diberikan perlakuan renang mengakibatkan timbulnya radikal bebas yang menyebabkan terjadinya kerusakan sel yang menyebabkan meningkatnya nilai leukosit. Sesuai penelitian Astawan et al. (2012) Respon inflamasi mengakibatkan terjadinya leukositosis atau peningkatan jumlah leukosit untuk meningkatkan kekebalan tubuh dalam mempertahankan kondisi tubuh. Leukositosis dilihat sebagai penanda adanya inflamasi kronik, subklinis dan inflamasi tingkat rendah, sedangkan tikus kelompok perlakuan (P2) menunjukkan nilai leukosit yang lebih rendah.

Hal ini kemungkinan ekstrak kulit pisang kepok memiliki kandungan yang mampu meredakan efek dari radikal bebas akibat perlakuan renang atau latihan intensif. Manurut Supriyanti et al. (2015) yang menyatakan ekstrak kulit pisang kepok memiliki aktivitas antioksidan yang tinggi, dengan aktivitas sebesar 95,14\%. Kadar leukosit tikus kelompok (P1) dan (P2) menunjukkan hasil yang berbeda nyata terhadap tikus perlakuan kontrol (P0) sehingga perlu dilakukan penambahan dosis ekstrak kulit pisang kepok untuk dapat memberikan hasil yang maksimal.

\section{Hematokrit (HCT)}

Hasil penelitian menunjukkan penurunan nilai hematokrit pada tikus kelompok perlakuan (P1) yang berbeda nyata terhadap tikus kelompok kontrol (P0), yang diduga diakibatkan oleh tingginya kadar radikal bebas yang memicu kerusakan sel-sel pada usus yang menyebabkan penyerapan nutrisi kurang baik dan juga mengganggu proses eritropoiesis (Astawan et al., 2011).

Radikal bebas dapat menganggu dari proses eritropoiesis dalam merangsang 
poliferasi sel eritosit yang menyebabkan menurunnya kadar eritrosit dalam darah, yang dimana akan berpengaruh dengan nilai hematokrit. Penurunan jumlah eritrosit, dan penurunan nilai hematokrit yang memiliki dampak juga pada penurunan kapasitas pengangkutan oksigen oleh darah dapat menyebabkan keadaan patologis seperti anemia (Zulkifli et al., 2014).

Nilai hematokrit pada tikus kelompok perlakuan (P2) yang diberikan perlakuan renang atau latihan intensif dan pemberian ekstrak kulit pisang kepok menunjukkan hasil yang tidak berbeda nyata terhadap tikus kelompok kontrol (P0). Hal ini mungkin disebabkan oleh kulit pisang kepok mengkal memiliki kadar vitamin $\mathrm{C}$ yang tinggi (Pary et al., 2016). Pemberian vitamin $\mathrm{C}$ membantu penyerapan zat besi (Fe) berperan pada proses pembentukan dan pematanganan dari eritrosit dalam darah (Sembiring et al., 2013).

\section{Mean Corpuscular Volume (MCV)}

Perubahan ukuran eritrosit dapat dipelajari secara kuantitatif dengan menghitung MCV (Fitrial et al., 2016). Hasil penelitian menunjukkan tikus kelompok perlakuan (P1) dan tikus perlakuan kelompok (P2), menunjukkan hasil yang tidak berbeda signfikan terhadap tikus kelompok kontrol (P0), namun dilihat dari rata rata standar deviasi kelompok perlakuan (P2) mengalami peningkatan nilai MCV walaupun menunjukan hasil yang tidak berbeda nyata mengindikasikan gambaran makrositik yaitu ukuran rata-rata eritrosit yang besar.

Pada anemia makrositik ukuran eritrosit bertambah besar dan jumlah hemoglobin tiap sel juga bertambah, anemia makrositik dibagi menjadi dua jenis anemia yaitu, anemia megaloblastik adalah kekurangan vitamin B12, asam folat dan gangguan sintesis DNA, dan anemia non megaloblastik adalah eritropolesis yang dipercepat dan peningkatan luas permukaan membran (Masrizal, 2007).

\section{Mean Corpuscular \\ Hemoglobin Concentration (MCHC)}

Hasil penelitian ini menunjukkan tikus kelompok perlakuan (P2) menunjukkan hasil yang tidak berbeda nyata terhadap tikus kelompok kontrol (P0), sedangkan tikus kelompok percobaan (P1) mengalami penurunan nilai MCHC yang menunjukkan hasil berbeda nyata terhadap tikus kelompok kontrol (P0). Means Corpuscular Haemoglobin Concentration (MCHC) merupakan nilai konsentrasi ratarata hemoglobin dalam total sel darah. Means Corpuscular Haemoglobin $(\mathrm{MCH})$ adalah kandungan hemoglobin tiap sel eritrosit (Rousdy dan Linda, 2018). Gambaran nilai MCHC yang menurun merupakan indikator sensitif untuk mendiagnosis defisiensi besi dengan dihitung menggunakan hematokrit. Kadar nilai MCHC dapat juga menjadi suatu indikasi dari sintesis abnormal hemoglobin, kegagalan osmoregulasi darah dan kegagalan osmolaritas plasma (Laloan et al., 2018).

\section{Nilai Deferensial Leukosit Neutrofil}

Hasil penelitian menunjukkan presentase neutrofil pada darah tikus putih, kelompok tikus kontrol (P0), tikus perlakuan (P1) dan tikus perlakuan renang (P2) menunjukkan hasil yang berbeda nyata. Standar deviasi menunjukkan tikus perlakuan (P2) menunjukkan hasil mendekati tikus kelompok kontrol (P0). Tikus perlakuan P1 dan P2 mengalami inflamasi yang mengakibatkan meningkatnya neutrofil, sesuai dengan penelitian Susanti., (2017) Neutrofil merupakan sel radang yang muncul pertama, sebagian besar disebabkan oleh mobilitasnya yang tinggi dan juga karena neutrofil terdapat dalam jumlah yang banyak dalam sirkulasi darah, neutrofil telah aktif pada awal reaksi radang sehingga neutrofil dapat dijadikan penanda inflamasi yang baru dimulai, hal ini tampak pada tikus perlakuan antara (P1) dan (P2) yang menunjukkan terjadinya inflamasi, namun jika dilihat dari nilai rata-rata 
deviasi menunjukkan bahwa tikus perlakuan renang dan ekstrak kulit pisang kepok (P2) menggambarkan terjadinya penurunan inflamasi, jika dibandingkan dengan tikus kelompok perlakuan renang (P1).

\section{Limfosit}

Hasil penelitian kadar limfosit tikus kelompok perlakuan renang (P1) dengan tikus kelompok perlakuan renang dan pemberian ekstrak kulit pisang kepok (P2) mengalami peningkatan dan menunjukkan hasil yang tidak berbeda nyata, sedangkan terhadap tikus kelompok kontrol (P0) menunjukkan hasil yang berbeda nyata. Tikus perlakuan P1 dan P2 mengalami stress dan adanya antigen sehingga deferensial leukosit limfosit meningkat, sesuai dengan penelitian Salasia dan Hariono. (2010) limfosit bertugas merespon adanya antigen dan stress dengan meningkatkan sirkulasi antibodi dalam pengembangan sistem imun. Peningkatan jumlah limfosit terjadi karena adanya benda asing yang masuk ke dalam jaringan, sehingga limfosit menerobos jaringan atau organ lunak yang berguna untuk penyediaan zat kebal bagi pertahanan tubuh (Melia et al., 2012).

\section{Eosinofil}

Eosinofil merupakan bagian dari diferensial leukosit yang dibentuk dalam sumsum tulang belakang yang berfungsi sebagai respon parasitik, peradangan dan alergi (Purnomo et al., 2015). Hasil penelitian kadar eusinofil menunjukkan tikus kelompok perlakuan (P1) dan tikus kelompok perlakuan (P2) dengan tikus kelompok kontrol (P0) menunjukkan hasil yang tidak berbeda nyata, yang disebabkan masih berlangsungnya proses inflamasi sesuai dengan meningkatnya deferensial leukosit neutrofil yang menyebabkan deferensial eosinofil belum mengeluarkan enzim untuk menetralkan faktor radang, sesuai dengan penelitian Lokapirnasari dan Yulianto. (2014) menyatakan bahwa eosinofil memiliki dua fungsi utama yaitu mampu menyerang dan menghancurkan bakteri patogen serta mampu menghasilkan enzim yang dapat menetralkan faktor radang, dalam mencegah masuknya infeksi pada tubuh, eosinofil bekerja dengan fungsi kimiawi secara enzimatik. Menurut Purnomo et al. (2015), tingginya persentase eosinofil dalam darah belum dapat diasumsikan bahwa keadaan dari mahluk hidup berada pada kondisi sakit, tingginya produksi eosinofil juga dapat menunjukkan berfungsinya sistem pertahanan tubuh dalam menghadapi agen penyakit. Sedangkan menurut Jannah et al. (2017), pemberian ekstrak kulit pisang kepok yang direspon sebagai benda asing sehingga tubuh merespon dengan meningkatkan eusinofil, namun pada pemberian ekstrak kulit pisang kepok dengan dosis yang lebih tinggi presentase eusinofil menjadi normal.

\section{Monosit}

Monosit merupakan diferensial leukosit yang termasuk kedalam kelompok Monosit merupakan diferensial leukosit yang termasuk kedalam kelompok agranulosit yang dibentuk di sumsum tulang dan mengalami pematangan ketika masuk kedalam sirkulasi sehingga menjadi makrofag dan masuk ke jaringan (Purnomo et al., 2015). Hasil penelitian menunjukkan tikus kelompok perlakuan renang $(\mathrm{P} 1)$ dan tikus kelompok perlakuan renang dengan pemberian ekstrak kulit pisang kepok (P2), menunjukkan hasil yang tidak berbeda nyata terhadap tikus kelompok kontrol (P0). Monosit merupakan pertahanan kedua terhadap terjadinya proses inflamasi yang dimana pertahanan pertama dari proses inflamasi adalah deferensial leukosit neutrofil, sesuai dengan penelitian Frandson et al (2009) mengatakan bahwa monosit mampu memfagositosis $100 \mathrm{sel}$ bakteri patogen dan menjadi sistem pengatur ketika terjadi peradangan dan merespon kekebalan, monosit dimobilisasi bersama dengan heterofil sehingga disebut sebagai pertahanan kedua terhadap peradangan, dan monosit dalam peredaran darah dapat dijadikan sebagai indikator kemampuan ternak dalam mekanisme 
penghancuran partikel asing dan sel mati, monosit berperan sebagai makrofag, yakni menelan dan menghancurkan sel mati, mikroorganisme dan benda asing yang bersifat pathogen.

\section{SIMPULAN DAN SARAN}

\section{Simpulan}

Pemberian ekstrak kulit pisang kepok 1cc pada tikus jantan dengan bobot badan 200-225g, ekstrak pisang kepok dapat mempertahankan kadar hemoglobin dan eritrosit namun belum dapat mempertahankan kadar leukosit dan nilai deferensial leukosit. Kadar HCT dan MCHC pada kelompok yang hanya diberikan diberikan Latihan intensif menunjukan hasil nyata lebih rendah dari kontrol, sedangkan pada kelompok tikus yang diberikan ekstrak dan latihan intensif menunjukan hasil tidak berbeda dengan kontrol. Kadar MCV baik yang hanya diberikan Latihan intensif maupun yang diberikan ekstrak pisang kapok menunjukan hasil tidak berbeda dengan kontrol.

\section{Saran}

Perlu dilakuakan penelitian lebih lanjut mengenai penggunaan ekstrak kulit pisang kepok (musa paradisiaca formatypica) dengan berbagai macam dosis, untuk melihat efektivitas dari ekstrak kulit pisang kepok (musa paradisiaca formatypica) hematologi tikus yang diberikan aktivitas fisik yang berlebihan.

\section{UCAPAN TERIMAKASIH}

Penulis mengucapkan terima kasih kepada UPT. Balai Laboratorium Kesehatan Provinsi Bali, Laboratorium Biokimia Veteriner Universitas Udayana, Laboratorium Radiologi Veteriner, Rumah Sakit Hewan Universitas Udayana, serta semua pihak yang telah membantu dalam penyelesaian penelitian ini.

\section{DAFTAR PUSTAKA}

Adawiah DS, Muawanah A. 2015. Aktivitas antioksidan dan kandungan komponen bioaktif sari buah namnam. J. Penelitian dan PengembanganIlmu Kimia. 1(2): 130-136.

Astawan M, Wresdiyati T, Ariefc II, Suhesti E. 2011. Gambaran hematologi tikus putih (Rattus norvegicus) yang diinfeksi escherichia coli enteropatogenik dan diberikan probiotik. Media Peternakan. 34(1): 713.

Astawan M, Wresdiyati T, Suliantari, Nabababan YMS. 2012. Yoghurt sinbiotik berbasis probiotik lokal dapat mencegah diare dan mengubah status hematologi tikus. J. Vet. 13(2): 145153.

Fitrial L, Illiy LL, Dewi IR. 2016. Pengaruh antikoagulan dan waktu penyimpanan terhadap profil hematologis tikus (Rattus norvegicus Berkenhout, 1769) galur wistar. Majalah Ilmiah Biologi BIOSFERA. 33(1): 22-30

Frandson RD, Wike WL, Fails AD. 2009. Anatomy and physiology of farm animal. $7^{\text {th }}$ Ed. Willey-Blackwell, Iowa: A John Wiley \& Sons, Inc.

Ghasemian A, Mehrabian S, Majd A. 2006. Peel extracts of two iranian cultivars of pomegranate (Punica granatum) have antioxidant and antimutagenic activities. Pakistan J. Biol. Sci. 9(7): 1402-1405.

Handayan S, Najib A, Wati NP. 2018. Uji aktivitas antioksidan ekstrak daun daruju (Acanthus Ilicifolius L.) dengan metode peredaman radikal bebas $1,1-$ Diphenyil-2-Picrylhidrazil (Dpph). J. Fitofarmaka Indonesia. 5(2): 299-308.

Helmi A, Vivi D, Almahdy. 2007. Pengaruh pemberian Vitamin $\mathrm{c}$ terhadap fetus pada mencit diabetes. $J$. Sains dan Teknol. Farmasi. 12(1): 3240.

Heryani LGSS, Susari NNW, Kardena IM, Laksmi DNDI. 2011. Paparan formalin menghambat proses spermatogenesis pada mencit. J. Vet. 12(3): 214-215.

Ihedioha JI, Ugwuja JI, Noel-Uneke OA, Udeani IJ, Daniel-Igwe G. (2012). Reference values for the haemotology 
profile of conventional grade outbred albino mice (Mus musculus) in Nsukka, Eastern Nigeria. Anim. Res. Int. 9(2): 1601-1612.

Jami'ah SR, Ifaya M, Pusmarani J, Nurhikma E. 2018. Uji aktivitas antioksidan ekstrak metanol kulit pisang raja (Musa Paradisiaca sapientum) dengan metode DPPH (2,2Difenil-1-Pikrilhidrazil). J. Mandala Pharmacon Indonesia. 4(1): 33-38.

Jannah PN, Sugiharto, Isroli. 2017. Jumlah leukosit dan differensiasi leukosit ayam broiler yang diberi minum air rebusan kunyit. J. Trop. Anim. Prod. 18(1): 1519.

Julfitriyani, Runtuwene RM, Wewengkang D. 2016. Uji aktivitas antioksidan dan toksisitas ekstrak etanol daun foki sabarati (Solanum Torvum). Pharmacon. 5(3): 94-101.

Laloan RJ, Marunduh AR, Sapulete IM. 2018. Hubungan merokok dengan nilai indeks eritrosit (MCV, $\mathrm{MCH}, \mathrm{MCHC})$ pada mahasiswa perokok. J. Medik dan Rehabilitasi. 1(2): 1-6.

Lokapirnasari WP, Yulianto, AB. 2014. Observation of eosinophils, monocytes, and basophils after treated with Spirulina in chickens that infected with avian influenza virus. J. Vet. 15(4): 499-505.

Melia J, Amrozi, Tumbelaka LI, Fahrimal Y. 2012. Identifikasi leukosit polymorphonuclear (pmn) dalam darah sapi endometritis yang diterapi dengan gentamisin, flumequin, dan analog Pgf2 $\alpha$. J. Vet. Sci. 6(2): 2502-5600.

Moniharapon PJ, Queljoe ED, Simbala H. 2016. Identifikasi fitokimia dan uji aktivitas antioksidan ekstrak etanol tauge (Phaseolus radiatus L). J. Ilmiah Farmasi. 5(4): 130-136.

Pary C, Masita, Safitrah A, Setiyawati E. 2016. Analisis kandungan gizi limbah kulit pisang kepok (musa paradisiaca formatypica) sebagai bahan baku kerupuk. Biosel: Biol. Sci. Ed. 5(1): 112-123.
Purnomo D, Sugiharto, Isroli. 2015. Total leukosit dan diferensial leukosit darah ayam broiler akibat penggunaan tepung onggok fermentasi rhizopus oryzae pada ransum. J. Ilmu-Ilmu Peternakan. 25(3): 59-68.

Rousdy DW, Linda R. 2018. Hematologi perbandingan hewan vertebrata: lele (Clarias batracus), katak (Rana sp.), kadal (Eutropis multifasciata), merpati (Columba livia) dan mencit (Mus musculus). Bioma: J. Ilmiah Biologi. 7(1): 1-13.

Rusmini H, Fitriani D, Hermawan D, Emilda DA. 2019. Pengaruh Vitamin D3 terhadap kadar hemoglobin tikus wistar yang dipapar asap rokok. ARTERI: J. Ilmu Kesehatan. 1(1); 22-28.

Salasia SHIO, Hariono B. 2010. Patologi klinik veteriner: Kasus patologi klinis. $2^{\text {nd }} E d$. Yogyakarta. Samudra Biru.

Sembiring A, Tanjung M., Sabri E. 2013. Pengaruh ekstrak segar daun rosela (Hibiscus sabdariffa l) terhadap jumlah eritrosit dan kadar hemoglobin mencit jantan (mus musculus 1) anemia strain ddw melalui induksi natrium nitrit (Nano2). Saintia Biologi. 1(2): 60-66.

Setiawan DW, Sinaga AR, Dewi TK. 2013. Proses pembuatan bioetanol dari kulit pisang kepok. J. Teknik Kimia. 19(1): 915.

Supriyanti FMT, Suanda H, Rosdiana R. 2015. Pemanfaatan ekstrak kulit pisang kepok (musa bluggoe) sebagai sumber antioksidan pada produksi tahu. Proc. Seminar Nasional Kimia dan Pendidikan Kimia VII, Universitas Sebelas Maret Surakarta, Surakarta, 18 April 2015. Pp: 393-400.

Suryanty RN, Rosdiana, Lubis B. 2005. Peran eritropoietin pada anemia. J. Sari Pediati. 7(1): 34-35.

Susanti, G. 2017. Efek anti inflamasi ekstrak daun binahong [anredera cordifolia (ten.) steenis] topikal terhadap jumlah pmn neutrofil pada 
tikus jantan sprague dawley. $J$. Kesehatan. 8(3): 351-357

Wibowo A, Joko T, Subandiyah S. 2010.

Increase resistance of kepok kuning bananaagainst blood disease through somaclonal variation and endophytic symbiosis. J. Perlindungan Tanaman Indonesia. 16(1): 15-21.

Zaetun S, Dewi LBK, Wiadnya IBR. 2018. Profil kadar mda (malondialdehide) sebagai penanda kerusakan seluler akibat radikal bebas pada tikus yang diberikan air beroksigen. J. Analis Medika Bio Sains. 5(1): 63-68

Zulkifli, Diarti MW, Jiwantarum Y, Saraswati L. 2014. Jumlah Eritrosit Darah Tepi Hewan Coba Tikus Putih (Rattus Norvegicus) Strain Wistar Yang Diberikan Air Seduhan Kelopak Bunga Rosela Merah (Hibiscuss Sabdariffa). Media Bina Ilmiah. 8(4):11-17. 